\title{
PENATAAN RUANG BERDASARKAN FUNGSI KAWASAN DI LERENG GUNUNGAPI SINDORO
}

\author{
Oleh : Hendro Murtianto*)
}

\begin{abstract}
Abstrak
Lereng Gunungapi Sindoro mempunyai lahan kehutanan yang seharusnya berdasarkan fungsinya digunakan sebagai kawasan perlindungan dan konservasi sumberdaya alam, mengalami alih fungsi lahan menjadi lahan pertanaian sehingga menimbulkan suatu aspek negatif berupa penggundulan hutan yang kemudian dijadikan lahan pertanian, tanpa memikirkan potensi dampak yang timbul dikemudian hari. Lahan kehutanan yang berada di lereng Gunungapi Sindoro mengalami perubahan fungsi dari kawasan hutan menjadi kawasan budidaya pertanian yang kurang memperhatikan lingkungan alaminya, hal ini terlihat dari pemanfaatan lahan yang tidak sesuai dengan karakteristik fisik dan daya dukung wilayahnya. Untuk menanggulangi dampak negatif yang mungkin terjadi akibat kegiatan tersebut, maka perlu adanya suatu perumusan penataan ruangberdasarkan fungsi kawasan yang harus ditaati oleh berbagai pihak guna mendukung kelestarian lingkungan dan pemanfaatan ruang yang berkelanjutan. Penentuan fungsi kawasan untuk pemanfaatan tertentu dilakukan dengan pertimbangan-pertimbangan karakteristik fisik dan sosial kemasyarakatan. Penataan ruang perlu dilakukan oleh berbagai pihak baik pemerintah ataupun masyarakat, guna saling mendukung program kelestarian lingkungan dan keruangan suatu wilayah. Pemanfaatan ruang yang sesuai dengan kemampuan wilayahnya diharapkan dapat memberikan dukungan bagi terpeliharanya lingkungan secara lestari dan mendukung bagi kehidupan manusia secara berkelanjutan.
\end{abstract}

Kata Kunci : Penataan Ruang, Fungsi Kawasan

\section{Pendahuluan}

Lereng Gunungapi Sindoro, Jawa Tengah; mempunyai kemiringan antara 15 sampai 40 persen dengan tanah sebagian telah rusak akibat erosi oleh air (BPN Kabupaten Temanggung Tahun 2003). Kemiringan lereng yang bervariasi tersebut mempunyai potensi cukup besar terjadinya erosi, ditambah lagi dengan curah hujan yang relatif tinggi. Dengan dibukanya lahan hutan milik Departemen Kehutanan yang ada di lereng Gunungapi Sindoro yang mempunyai kemiringan lebih dari 40 persen untuk lahan pertanian, menyebabkan tanaman pelindung dan penahan erosi air menjadi berkurang untuk menahan curah hujan yang tinggi sepanjang tahunnya. Jenis tanah yang ada di Lereng Gunungapi Sindoro, Jawa Tengah adalah kompleks tanah Andisols yang seharusnya mempunyai kelembapan yang tinggi untuk mengendalikan erosi. Hal ini karena struktur tanah Andisols masih dalam perkembangan, maka jika tanah ini dalam keadaan terbuka atau tidak bervegetasi akan mudah tererosi. Tanah Andisols dalam kondisi jenuh air, dapat dengan mudah terbawa oleh limpasan air permukaan yang menyebabkan erosi. Sebaliknya,

*) Hendro Murtianto, S.Pd., M.Si., adalah Dosen Jurusan Pendidikan Geografi FPIPS-UPI. 
dalam kondisi kering karena sifat berat isi tanahnya yang ringan, maka tanah tersebut juga mudah terbawa oleh angin. Oleh karena itu, Andisols harus selalu tertutup vegetasi baik berupa hutan maupun rumput penutup lahan. Berdasarkan sifat-sifat tanah yang tersebut, maka potensi terjadinya erosi besar.

Lereng Gunungapi Sindoro yang mempunyai ketinggian lebih dari 1000 meter dari permukaan air laut, dengan kondisi iklim yang konstan sepanjang tahun, sifat fisik dan kimia tanah relatif baik, maka para petani menanam tanaman yang mempunyai nilai ekonomi yang tinggi, yaitu tanaman tembakau. Tanaman tembakau ditanam serentak yang mengakibatkan terjadinya monokultur pertanian pada lereng tengah dan lereng bawah Gunungapi Sindoro, Kabupaten Temanggung. Lahan pertanian dengan topografi yang beragam dari bergelombang hingga bergunung, mempercepat terjadinya erosi tanah permukaan. Erosi yang terjadi didominasi oleh agen erosi air berupa hujan orografis yang besar, hal ini dapat diketahui dari banyaknya batuan induk yang tersingkap di permukaan tanah.

Lahan kehutanan yang semestinya dijadikan sebagai kawasan perlindungan dan konservasi sumberdaya alam, secara berangsur-angsur berubah jenis penggunaan lahannya. Hal ini karena adanya suatu program dari PT. Perhutani dan masyarakat untuk mengelola bersama hutan yang ada, sehingga menimbulkan suatu aspek negatif berupa penggundulan hutan yang kemudian dijadikan lahan pertanian, tanpa memikirkan potensi dampak yang timbul dikemudian hari. Lahan kehutanan yang berada di lereng Gunungapi Sindoro mengalami perubahan fungsi dari kawasan hutan menjadi kawasan budidaya pertanian yang kurang memperhatikan lingkungan alaminya, hal ini terlihat dari pemanfaatan lahan yang tidak sesuai dengan karakteristik fisik dan daya dukung wilayahnya.

Suatu bentuk yang semula melegalkan adanya pengelolaan bersama hutan dengan masyarakat adalah tetap menjaga fungsi hutan, berupa penanaman tanaman keras dan melakukan kegiatan wanatani, secara perlahan tanpa pengawasan yang baik dari pemerintah, mengalami suatu kemerosotan fungsi lahan berupa penggundulan hutan. Konsep pengelolaan hutan bersama masyarakat tidak berjalan dengan baik karena tuntutan ekonomi masyarakat yang menginginkan lahan tersebut dapat dimanfaatkan semaksimal mungkin, sehingga dapat memberi keuntungan yang lebih pada pengelolanya. Penanaman tanaman yang bernilai ekonomi tinggi adalah menanam tembakau pada musim kering. Kegiatan penanaman tembakau ini, menyebabkan timbul suatu gagasan untuk memperbanyak jumlah tanaman dengan cara mengurangi kanopi tanaman keras melalui pemangkasan daun ataupun dengan menebangnya, sehingga terjadi penebangan tanaman keras secara masal. Himbauan yang diberikan melalui penyuluhan dari Dinas Kehutanan Kabupaten Temanggung tentang konservasi lahan dan pembagian bibit tanaman keras, seperti kopi dan buah-buahan kurang mendapatkan respon dari penyewa lahan, yaitu masyarakat.

\section{Metode Penelitian}

a Satuan Lahan Daerah Penelitian

*) Hendro Murtianto, S.Pd., M.Si., adalah Dosen Jurusan Pendidikan Geografi FPIPS-UPI. 
Satuan lahan digunakan sebagai peta acuan dalam pengambilan sampel penelitian. Satuan lahan ini merujuk pada :

1) bentuk lahan yang dibagi menjadi, yaitu : lereng vulkan bagian tengah (V1) dan bawah (V2).

2) kemiringan lereng yang dibagi menjadi 5 kelas, yaitu : lereng 0-8 \% (I), 8-15\% (II), $15-30 \%$ (III), 30-40 \% (IV) dan > 40\% (V). Daerah penelitian setelah dianalisis dengan menggunakan software Arc View 3.3, hanya memiliki 4 kelas kemiringan lereng saja, karena kelerengan $0-8 \%$ (I) pada daerah penelitian secara general tidak ada atau keberadaannya tidak signifikan.

3) tanah yang ada di daerah penelitian mempunyai kesamaan ordo, yaitu: Tanah Andisols dan Sub-ordo Vitrans; akan tetapi terdapat perbedaan iklim yang mendasari perbedaan pada tingkatan great-groupnya, yaitu : Ustik dan Udik, sehingga untuk penggolongan tanah dibagi menjadi 2 jenis, yaitu : Typic Udivitrands (TUd) dan Typic Ustivitrands (TUs).

4) penggunaan lahan di daerah penelitian dibagi menjadi beberapa macam penggunaan lahan, yaitu : kebun $(\mathrm{Kb})$, tegalan $(\mathrm{Tg})$, sawah tadah hujan $(\mathrm{St})$, semak belukar ( $\mathrm{Sb}$ ) dan pemukiman (P). Penggunaan lahan yang digunakan acuan pada penelitian ini dibatasi pada penggunaan lahan garapan pertanian dan perkebunan, yaitu penggunaan lahan kebun, tegalan dan sawah tadah hujan.

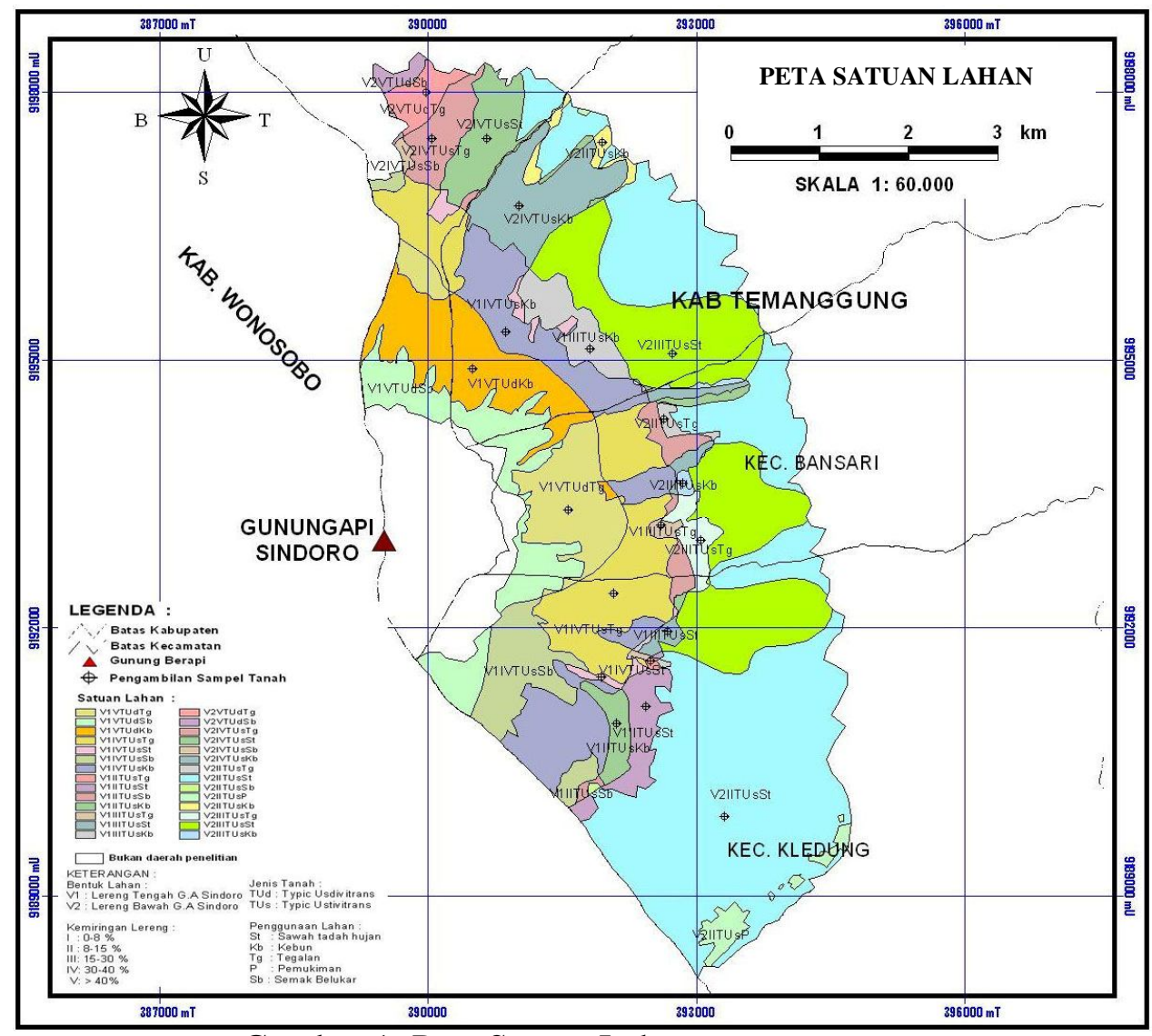

Gambar 1: Peta Satuan Lahan

*) Hendro Murtianto, S.Pd., M.Si., adalah Dosen Jurusan Pendidikan Geografi FPIPS-UPI. 
b Penentuan fungsi kawasan

Penentuan fungsi kawasan di daerah penelitian berdasarkan SK Menteri Pertanian No. 837/Kpts/Um/11/1980 dan No.: 683/Kpts/Um/8/1981 tentang kriteria dan tata cara penetapan hutan lindung dan hutan produksi. Kriteria Penetapan Fungsi Kawasan melalui penilaian tiga variabel karakteristik lahan, yaitu: kelerengan lapangan, jenis tanah menurut kepekaan terhadap erosi, intensitas hujan harian rata - rata. Informasi tersebut didapatkan dari hasil pengolahan peta topografi, peta tanah, dan data hujan. Klasifikasi dan nilai skor dari ketiga faktor di atas berturut - turut adalah seperti yang ditunjukkan pada tabel berikut ini:

Tabel 1, Klasifikasi dan Nilai Skor Faktor Kemiringan Lereng

\begin{tabular}{|c|c|c|c|}
\hline Kelas & Kelerengan & Klasifikasi & Nilai Skor \\
\hline I & $0-8 \%$ & Datar & 20 \\
\hline II & $8-15 \%$ & Landai & 40 \\
\hline III & $15-25 \%$ & Agak Curam & 60 \\
\hline IV & $25-40 \%$ & Curam & 80 \\
\hline V & $>40 \%$ & Sangat Curam & 100 \\
\hline
\end{tabular}

(Pedoman Penyusunan RLKT : 1994)

Tabel 2, Klasifikasi dan Nilai Skor Faktor Jenis Tanah

\begin{tabular}{|l|l|l|c|}
\hline Kelas & \multicolumn{1}{|c|}{ Jenis Tanah } & Klasifikasi & Nilai Skor \\
\hline I & $\begin{array}{l}\text { Aluvial,Glei, Planosol,Hidromerf, Laterik air tanah } \\
\text { Aluvial,Glei, Planosol,Hidromerf, }\end{array}$ & Tidak peka & 15 \\
\hline II & Latosol & Kurang peka & 30 \\
\hline III & Brown forest soil, non calcic brown, mediteran & Peka & 45 \\
\hline IV & Andosol, Laterit, Grumusol, Podsol, Podsolic & Agak peka & 60 \\
\hline V & Regosol, Litosol, Organosol, Renzina & Peka & 75 \\
\hline
\end{tabular}

(Pedoman Penyusunan RLKT : 1994)

Tabel 3, Klasifikasi dan Nilai Skor Faktor Intensitas Hujan Harian Rata -Rata

\begin{tabular}{|l|l|l|c|}
\hline Kelas & Intensitas hujan & Klasifikasi & Nilai Skor \\
\hline I & $0-13,6$ & Sangat rendah & 10 \\
\hline II & $13,6-20,7$ & Rendah & 20 \\
\hline III & $20,7-27,7$ & Sedang & 30 \\
\hline IV & $27,7-34,8$ & Tinggi & 40 \\
\hline V & $>34,8$ & Sangat tinggi & 50 \\
\hline
\end{tabular}

(Pedoman Penyusunan RLKT : 1994)

Melalui overlay peta masing - masing faktor diatas, akan didapatkan satuan lahan menurut klasifikasi dan nilai skor dari ketiga tersebut. Penetapan fungsi kawasan dilakukan dengan menjumlahkan nilai skor dari ketiga faktor yang dinilai pada setiap satuan lahan. Besarnya jumlah nilai skor tersebut merupakan nilai skor kriteria fungsi kawasan. Jenis fungsi kawasan

*) Hendro Murtianto, S.Pd., M.Si., adalah Dosen Jurusan Pendidikan Geografi FPIPS-UPI. 
ditetapkan berdasarkan besarnya nilai skor kemampuan lahan dan kriteria khusus lainnya, sebagaimana kriteria dan tata cara yang ditetapkan dalam Buku Petunjuk Penyusunan Pola RLKT. Fungsi kawasan berdasarkan kriteria tersebut dibagi menjadi :

1) Kawasan Fungsi Lindung (Kode A)

Kawasan fungsi lindung adalah suatu wilayah yang keadaan sumberdaya alam air, flora dan fauna seperti hutan lindung, hutan suaka, hutan wisata, daerah sekitar sumber mata air, alur sungai, dan kawasan lindung lainnya sebagimana diatur dalam Kepres 32 Tahun 1990. Suatu lahan ditetapkan sebagai kawasan fungsi lindung, apabila besarnya skor lahannya $\geq 175$, atau memenuhi salah satu/beberapa syarat berikut :

a) Mempunyai kemiringan lahan lebih dari $40 \%$,

b) Jenis tanahnya sangat peka terhadap erosi (regosol, litosol, organosol, dan renzina) dengan kemiringan lapangan lebih dari $15 \%$,

c) Merupakan jalur pengaman aliran air/sungai yaitu sekurang-kurangnya 100 meter di kiri-kanan sungai besar dan 50 meter kiri-kanan anak sungai,

d) Merupakan perlindungan mata air, yaitu sekurang-kurangnya radius 200 meter di sekeliling mata air,

e) Merupakan perlindungan danau/waduk, yaitu 50-100 meter sekeliling danau/waduk,

f) Mempunyai ketinggian 2.000 meter atau lebih di atasa permukaan laut,

g) Merupakan kawasan Taman Nasional yang lokasinya telah ditetapkan oleh pemerintah,

h) Guna keperluan/kepentingan khusus dan ditetapkan sebagai kawasan lindung.

2) Kawasan Fungsi Penyangga (Kode B)

Kawasan fungsi penyangga adalah suatu wilayah yang dapat berfungsi lindung dan berfungsi budidaya, letaknya diantara kawasan fungsi lindung dan kawasan fungsi budidaya seperti hutan produksi terbatas, perkebunan (tanaman keras), kebun campur dan lainnya yang sejenis. Suatu satuan lahan ditetapkan sebagai kawasan fungsi penyangga apabila besarnya nilai skor lahannya sebesar 125-174 dan atau memenuhi kriteria umum sebagai berikut :

a) Keadaan fisik satuan lahan memungkinkan untuk dilakukan budidaya secara ekonomis,

b) Lokasinya secara ekonomis mudah dikembangkan sebagai kawasan penyangga,

c) Tidak merugikan dilihat darisegi ekologi/ lingkungan hidup bila dikembangkan sebagai kawasan penyangga.

3) Kawasan fungsi Budidaya Tanaman Tahunan (Kode C)

Kawasan fungsi budidaya tanaman tahunan adalah kawasan budidaya yang diusahakan dengan tanaman tahunan seperti Hutan Produksi Tetap, Hutan Tanaman Industri, Hutan Rakyat, Perkebunan (tanaman keras), dan tanaman buah - buahan. Suatu satuan lahan ditetapkan sebagai kawasan dengan fungsi budidaya tanaman tahunan apabila besarnya nilai skor lahannya $\leq 124$ serta

*) Hendro Murtianto, S.Pd., M.Si., adalah Dosen Jurusan Pendidikan Geografi FPIPS-UPI. 
mempunyai tingkat kemiringan lahan $15-40 \%$ dan memenuhi kriteria umum seperti pada kawasan fungsi penyangga.

4) Kawasan Fungsi Budidaya Tanaman Semusim (Kode D)

Kawasan fungsi budidaya tanaman semusim adalah kawasan yang mempunyai fungsi budidaya dan diusahakan dengan tanaman semusim terutama tanaman pangan atau untuk pemukiman. Untuk memelihara kelestarian kawasan fungsi budidaya tanaman semusim, pemilihan jenis komoditi harus mempertimbangkan keseuaian fisik terhadap komoditi yang akan dikembangkan. Untuk kawasan pemukiman, selain memiliki nilai kemampuan lahan maksimal 124 dan memenuhi kriteria tersebut diatas, secara mikro lahannya mempunyai kemiringan tidak lebih dari $8 \%$.

\section{Hasil Penelitian dan Pembahasan}

Hasil penjumlahan nilai skor tersebut merupakan suatu klasifikasi penentuan fungsi kawasan yang dianjurkan. Klasifikasi fungsi kawasan tersebut dibagi menjadi 4 kategori, yaitu:

a. Kawasan Lindung (Kode A)

Kawasan Lindung adalah suatu wilayah yang keadaan sumberdaya alam air, flora dan fauna seperti hutan lindung, hutan suaka, hutan wisata, daerah sekitar sumber mata air, alur sungai, dan kawasan lindung lainnya sebagimana diatur dalam Kepres 32 Tahun 1990. Kawasan lindung pada penelitian ini didapatkan dari penjumlahan nilai skor kelerengan, tanah dan intensitas hujan sebesar $\geq 175$ atau memenuhi salah satu kriteria sebagai berikut : (1) mempunyai kemiringan lereng $>40 \%$, (2) mempunyai ketinggian di atas $2000 \mathrm{~m}$ dpal.

Berdasarkan kriteria fisik tersebut, maka didapat suatu kawasan yang masuk dalam kategori kawasan lindung (A) dengan luasan sebesar 389,2 ha yang terbagi menjadi beberapa cakupan satuan lahan. Satuan lahan yang masuk ke dalam kawasan lindung ini adalah : Satuan lahan V1IVTUsKb seluas 0,67 ha, V1IVTUsTg seluas 16,8 ha, V1VTUdKb seluas 192,75 ha, V1VTUdTg seluas 146,08 dan V2VTUdTg seluas 32,9 ha.

\section{b. Kawasan Penyangga (Kode B)}

Kawasan fungsi penyangga adalah suatu wilayah yang dapat berfungsi lindung dan berfungsi budidaya, letaknya diantara kawasan fungsi lindung dan kawasan fungsi budidaya seperti hutan produksi terbatas, perkebunan (tanaman keras), kebun campur dan lainnya yang sejenis. Suatu satuan lahan ditetapkan sebagai kawasan fungsi penyangga apabila besarnya nilai skor karakteristik fisik lahannya sebesar 125-174 dan atau memenuhi salah satu kriteria umum sebagai berikut: (1) keadaan fisik satuan lahan memungkinkan untuk dilakukan budidaya secara ekonomis, (2) lokasinya secara ekonomis mudah dikembangkan sebagai kawasan penyangga, (3) tidak merugikan lingkungan hidup bila dikembangkan sebagai kawasan penyangga. Berdasarkan kriteria fisik tersebut, maka didapat suatu kawasan yang masuk dalam kategori kawasan penyangga (B) dengan luasan sebesar $1.398,7$ ha yang terbagi menjadi beberapa cakupan satuan

*) Hendro Murtianto, S.Pd., M.Si., adalah Dosen Jurusan Pendidikan Geografi FPIPS-UPI. 
lahan. Satuan lahan yang masuk ke dalam kawasan penyangga ini adalah: satuan lahan V1IIITUsKb seluas 62,6 ha, satuan lahan V1IIITUsSt seluas 9,7 ha, satuan lahan V1IIITUsTg seluas 7,5 ha, satuan lahan V2IIITUsKb seluas 8,2 ha, satuan lahan V2IIITUsSt seluas 450,5 ha, satuan lahan V2IIITUsTg seluas 30,3 ha, satuan lahan V1IVTUsKb seluas 247,8 ha, satuan lahan V1IVTUsSt seluas 22,8 ha, satuan lahan V2IVTUsKb seluas 247,2 ha, satuan lahan V2IVTUsSt seluas 128,3 ha, satuan lahan V2IVTUsTg seluas 93,5 ha, dan satuan lahan V1IVTUsTg seluas 90,3 ha.

\section{c. Kawasan Budidaya Tanaman Tahunan (Kode C)}

Kawasan fungsi budidaya tanaman tahunan adalah kawasan budidaya yang diusahakan dengan tanaman tahunan seperti Hutan Produksi Tetap, Hutan Tanaman Industri, Hutan Rakyat, Perkebunan (tanaman keras), dan tanaman buahbuahan. Suatu satuan lahan ditetapkan sebagai kawasan dengan fungsi budidaya tanaman tahunan apabila besarnya nilai skor kemampuan lahannya $\leq 124$ serta mempunyai tingkat kemiringan lahan $15-40 \%$ dan memenuhi kriteria umum seperti pada kawasan fungsi penyangga. Berdasarkan kriteria fisik tersebut, maka didapat suatu kawasan yang masuk dalam kategori kawasan budidaya tanaman tahunan (C) dengan luasan sebesar 1.178,6 ha yang terbagi menjadi beberapa cakupan satuan lahan, yaitu : satuan lahan V1IITUsKb seluas 28,6 ha, satuan lahan V1IITUsSt seluas 54,5 ha, satuan lahan V1IITUsTg seluas 1,8 ha, satuan lahan V2IITUsKb seluas 18,6 ha, satuan lahan V2IITUsSt seluas 1.066,1 ha, dan satuan lahan V2IITUsTg seluas 9 ha.

\section{d. Kawasan Budidaya Tanaman Semusim (Kode D)}

Kawasan fungsi budidaya tanaman semusim adalah kawasan yang mempunyai fungsi budidaya dan diusahakan dengan tanaman semusim terutama tanaman pangan atau untuk pemukiman. Untuk memelihara kelestarian kawasan fungsi budidaya tanaman semusim, pemilihan jenis komoditi harus mempertimbangkan kesesuaian fisik terhadap komoditi yang akan dikembangkan. Selain memiliki nilai kemampuan lahan maksimal 124 dan memenuhi kriteria lahan yang dapat dikembangkan sebagai kawasan budidaya dan secara kemiringan lerengnya tidak lebih dari $8 \%$. Daerah penelitian secara umum mempunyai kemiringan lereng > 8\%, maka pada daerah ini tidak terdapat lahan yang memenuhi kriteria kemiringan lereng tidak boleh lebih besar dari $8 \%$, sehingga di lokasi penelitian fungsi kawasan budidaya tanaman semusim tidak memenuhi syarat penanaman lahan dengan tanaman semusim saja. Penanaman lahan dengan tanaman semusim dapat dilakukan dengan mengintegrasikan pola penanaman lahan tanaman semusim diantara tanaman inti atau tanaman keras yang berada di lokasi penelitian.

*) Hendro Murtianto, S.Pd., M.Si., adalah Dosen Jurusan Pendidikan Geografi FPIPS-UPI. 


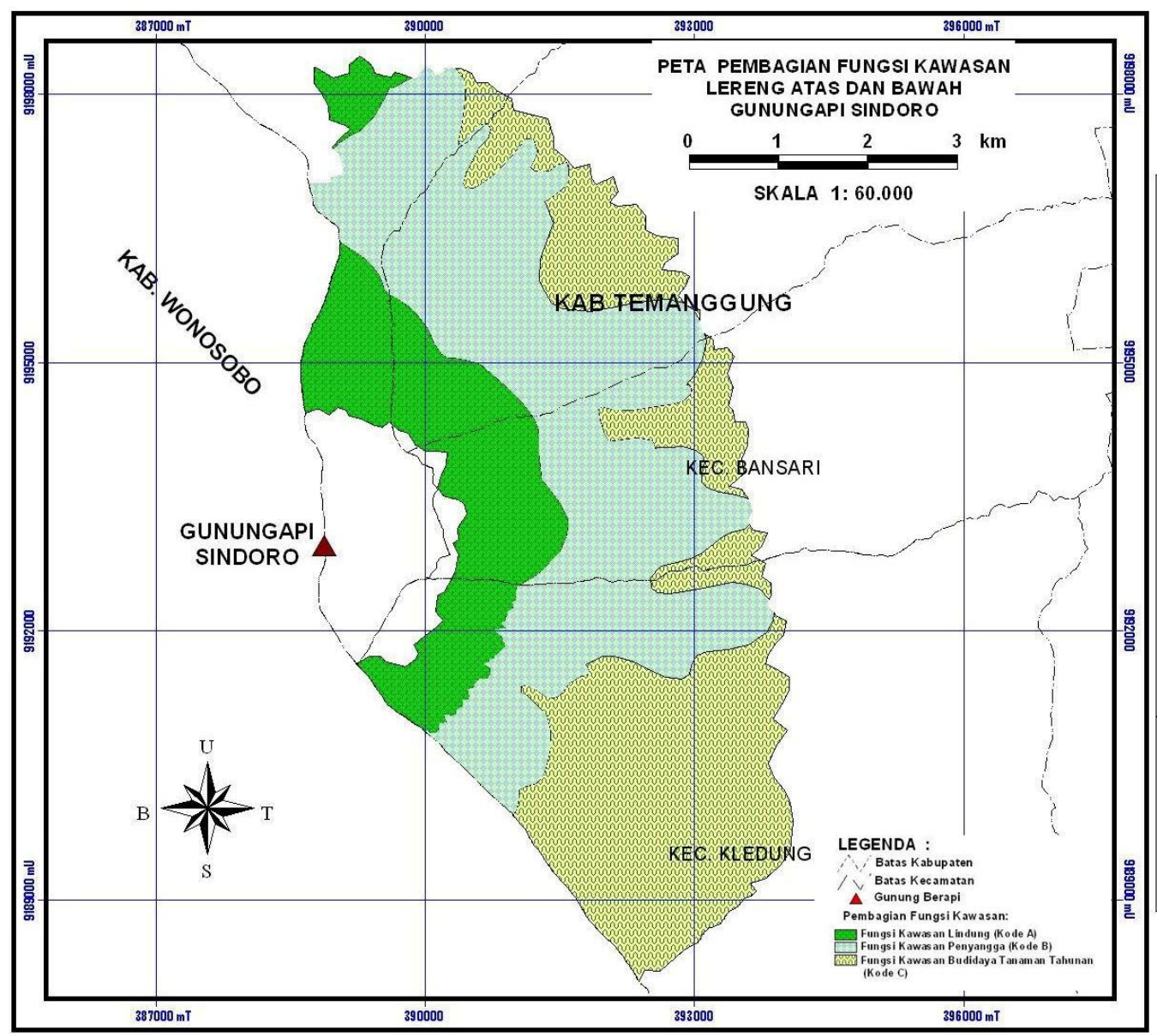

Gambar 2: Peta pembagian fungsi kawasan lereng atas dan bawah gunungapi Sindoro

Tabel 4. Penentuan Fungsi Kawasan Daerah Penelitian

\begin{tabular}{|c|c|c|c|c|c|c|c|c|c|c|c|}
\hline \multirow[b]{2}{*}{$\begin{array}{l}\text { Satuan } \\
\text { Lahan }\end{array}$} & \multicolumn{2}{|c|}{$\begin{array}{c}\text { Kemiringan } \\
\text { Lereng }\end{array}$} & \multicolumn{2}{|c|}{ Jenis Tanah } & \multicolumn{2}{|c|}{$\begin{array}{c}\text { Hujan Harian } \\
\text { Rata-rata } \\
\text { (cm) }\end{array}$} & \multirow[b]{2}{*}{$\begin{array}{l}\text { Jumlah } \\
\text { Skor }\end{array}$} & \multicolumn{2}{|c|}{ Faktor Pembatas } & \multirow[b]{2}{*}{$\begin{array}{l}\text { Luas } \\
\text { (Ha) }\end{array}$} & \multirow[b]{2}{*}{$\begin{array}{c}\text { Penentuan Fungsi } \\
\text { Kawasan }\end{array}$} \\
\hline & $\%$ & Skor & Tanah & Skor & $\mathbf{r}$ & Skor & & Lereng & Ketinggian & & \\
\hline V1IITUsKb & 12,2 & 40 & Andisols & 60 & 11,6 & 10 & 110 & $>8 \%$ & & 28,6 & Tanaman Tahunan \\
\hline V1IITUsSt & 10 & 40 & Andisols & 60 & 11,6 & 10 & 110 & $>8 \%$ & & 54,5 & Tanaman Tahunan \\
\hline V1IITUsTg & 12 & 40 & Andisols & 60 & 11,6 & 10 & 110 & $>8 \%$ & & 1,8 & Tanaman Tahunan \\
\hline V2IITUsKb & 9,5 & 40 & Andisols & 60 & 11,6 & 10 & 110 & $>8 \%$ & & 18,6 & Tanaman Tahunan \\
\hline V2IITUsSt & 12 & 40 & Andisols & 60 & 11,6 & 10 & 110 & $>8 \%$ & & 1066,1 & Tanaman Tahunan \\
\hline V2IITUsTg & 12 & 40 & Andisols & 60 & 11,6 & 10 & 110 & $>8 \%$ & & 9,0 & Tanaman Tahunan \\
\hline V1IIITUsKb & 20,5 & 60 & Andisols & 60 & 11,6 & 10 & 130 & & & 62,6 & Penyangga \\
\hline V1IIITUsSt & 18 & 60 & Andisols & 60 & 11,6 & 10 & 130 & & & 9,7 & Penyangga \\
\hline V1IIITUsTg & 20.5 & 60 & Andisols & 60 & 11,6 & 10 & 130 & & & 7,5 & Penyangga \\
\hline V2IIITUsKb & 15 & 60 & Andisols & 60 & 11,6 & 10 & 130 & & & 8,2 & Penyangga \\
\hline V2IIITUsSt & 16,5 & 60 & Andisols & 60 & 11,6 & 10 & 130 & & & 450,5 & Penyangga \\
\hline
\end{tabular}

*) Hendro Murtianto, S.Pd., M.Si., adalah Dosen Jurusan Pendidikan Geografi FPIPS-UPI. 


\begin{tabular}{|l|c|c|l|l|l|l|l|l|l|l|l|} 
V2IIITUsTg & 20,5 & 60 & Andisols & 60 & 11,6 & 10 & 130 & & & 30,3 & Penyangga \\
\hline V1IVTUsKb & 34,6 & 80 & Andisols & 60 & 11,6 & 10 & 150 & & $>2000 \mathrm{~m}$ & 0,67 & Lindung \\
\hline & & & & & & & & & & 247,8 & Penyangga \\
\hline V1IVTUsSt & 30 & 80 & Andisols & 60 & 11,6 & 10 & 150 & & & 22,8 & Penyangga \\
\hline V1IVTUsTg & 35 & 80 & Andisols & 60 & 11,6 & 10 & 150 & & $>2000 \mathrm{~m}$ & 16,8 & Lindung \\
\hline & & & & & & & & & & 247,2 & Penyangga \\
\hline V2IVTUsKb & 31 & 80 & Andisols & 60 & 11,6 & 10 & 150 & & & 138,3 & Penyangga \\
\hline V2IVTUsSt & 32 & 80 & Andisols & 60 & 11,6 & 10 & 150 & & & 93,5 & Penyangga \\
\hline V2IVTUsTg & 38,5 & 80 & Andisols & 60 & 11,6 & 10 & 150 & & & 90,3 & Penyangga \\
\hline V1VTUdKb & 53 & 100 & Andisols & 60 & 11,6 & 10 & 170 & $>40 \%$ & $>2000 \mathrm{~m}$ & 192,75 & Lindung \\
\hline V1VTUdTg & 62 & 100 & Andisols & 60 & 11,6 & 10 & 170 & $>40 \%$ & $>2000 \mathrm{~m}$ & 146,08 & Lindung \\
\hline V2VTUdTg & 70 & 100 & Andisols & 60 & 11,6 & 10 & 170 & $>40 \%$ & $>2000 \mathrm{~m}$ & 32,9 & Lindung \\
\hline
\end{tabular}

(Sumber : Hasil Perhitungan ,2008)

\section{Kondisi Sosial Ekonomi Masyarakat}

a Jumlah Penduduk

Berdasarkan data dari Bapeda Kabupaten Temanggung Tahun 2006, jumlah penduduk yang terdapat di empat kecamatan lindung, yaitu sebanyak 125.244 jiwa, yang terbagi atas jumlah penduduk Kecamatan Ngadirejo sebanyak 49.280 jiwa dengan tingkat kepadatan penduduk $924 / \mathrm{km}^{2}$, Kecamatan Kledung sebanyak 25.021 jiwa dengan tingkat kepadatan penduduk $777 / \mathrm{km}^{2}$, Kecamatan Candiroto sebanyak 29.286 jiwa dengan tingkat kepadatan penduduk $486 / \mathrm{km}^{2}$, dan Kecamatan Bansari sebanyak 21657 dengan tingkat kepadatan penduduk 961/km².

\section{b Tingkat Kemiskinan}

Jumlah Keluarga miskin yang terdapat di tiga kecamatan lindung, yaitu sebanyak $10.322 \mathrm{KK}$ dan yang tidak miskin sebanyak $22721 \mathrm{KK}$, yang terbagi atas jumlah penduduk Kecamatan Ngadirejo sebanyak $3461 \mathrm{KK}$ miskin serta $9256 \mathrm{KK}$ tidak miskin atau sebesar 27,2 \% KK miskin, Kecamatan Kledung sebanyak 1957 KK miskin serta $4773 \mathrm{KK}$ tidak miskin atau sebesar 29,1\% KK miskin, Kecamatan Candiroto sebanyak $3218 \mathrm{KK}$ miskin serta $4401 \mathrm{KK}$ tidak miskin atau sebesar 42,2 \% KK miskin dan Kecamatan Bansari sebanyak 1686 KK miskin serta $4291 \mathrm{KK}$ tidak miskin atau sebesar 28,2 \% KK miskin.

\section{c Status Kepemilikan Lahan}

Luas lahan di daerah penelitian adalah 3344,4 Ha yang terbagi atas dua status kepemilikan lahan, yaitu tanah kehutanan seluas 1985,6 Ha dan tanah milik penduduk seluas 1358,8 Ha. Lahan kehutanan yang semestinya dijadikan sebagai kawasan perlindungan dan konservasi sumberdaya alam, secara berangsur-angsur berubah jenis penggunaan lahannya. Hal ini karena adanya suatu program dari PT. Perhutani dan masyarakat untuk mengelola bersama hutan yang ada, sehingga menimbulkan suatu aspek negatif berupa penggundulan hutan yang kemudian dijadikan lahan pertanian, tanpa memikirkan potensi dampak yang timbul dikemudian hari. Lahan kehutanan yang berada di lereng Gunungapi Sindoro mengalami perubahan fungsi dari kawasan hutan menjadi kawasan budidaya

*) Hendro Murtianto, S.Pd., M.Si., adalah Dosen Jurusan Pendidikan Geografi FPIPS-UPI. 
pertanian yang kurang memperhatikan lingkungan alaminya, hal ini terlihat dari pemanfaatan lahan yang tidak sesuai dengan karakteristik fisik dan daya dukung wilayahnya.

Tabel 5, Perbandingan Status Kepemilikan Lahan dan Penggunaan Lahan Tahun 2006

\begin{tabular}{|c|c|c|c|}
\hline KECAMATAN & $\begin{array}{c}\text { STATUS } \\
\text { KEPEMILIKAN }\end{array}$ & $\begin{array}{c}\text { PENGGUNAAN } \\
\text { LAHAN }\end{array}$ & $\begin{array}{c}\text { LUAS } \\
\text { (Ha) }\end{array}$ \\
\hline \multirow[t]{8}{*}{ KEC. NGADIREJO } & Tanah Kehutanan & Tegalan & 0,2 \\
\hline & & Kebun & 260,2 \\
\hline & & Semak belukar & 32 \\
\hline & & Sawah tadah hujan & 145,7 \\
\hline & Tanah Milik & Tegalan & 15,4 \\
\hline & & Kebun & 119,2 \\
\hline & & Pemukiman & 1,1 \\
\hline & & Sawah tadah hujan & 300,5 \\
\hline \multirow[t]{6}{*}{ KEC. KLEDUNG } & Tanah Kehutanan & Tegalan & 122 \\
\hline & & Kebun & 138,5 \\
\hline & & Semak belukar & 168,1 \\
\hline & & Sawah tadah hujan & 337,6 \\
\hline & Tanah Milik & Pemukiman & 30,4 \\
\hline & & Sawah tadah hujan & 568,4 \\
\hline \multirow[t]{9}{*}{ KEC. CANDIROTO } & Tanah Kehutanan & Semak belukar & 66,1 \\
\hline & & Tegalan & 96 \\
\hline & & Pemukiman & 0,3 \\
\hline & & Sawah tadah hujan & 17,8 \\
\hline & & Kebun & 79,6 \\
\hline & Tanah Milik & Tegalan & 61,3 \\
\hline & & Sawah tadah hujan & 86,5 \\
\hline & & Kebun & 0,2 \\
\hline & & Semak belukar & 8,3 \\
\hline \multirow[t]{6}{*}{ KEC. BANSARI } & Tanah Kehutanan & Kebun & 61 \\
\hline & & Semak belukar & 58 \\
\hline & & Tegalan & 287,6 \\
\hline & & Sawah tadah hujan & 115,2 \\
\hline & Tanah Milik & Kebun & 3,9 \\
\hline & & Sawah tadah hujan & 159,7 \\
\hline
\end{tabular}

(Sumber : hasil perhitungan, 2008)

\section{Strategi Aplikasi Penataan Kawasan}

Penerapan konsep konservasi lahan secara menyeluruh merupakan penerapan bentuk konservasi lahan, pemberdayaan sosial masyarakat dan penegasan aturan hukum yang berlaku.

*) Hendro Murtianto, S.Pd., M.Si., adalah Dosen Jurusan Pendidikan Geografi FPIPS-UPI. 


\section{a. Konservasi Lahan}

Hasil evaluasi lahan dan pewilayahan komoditas pertanian, tanaman semusim (palawija dan sayur/ buah semusim), diutamakan pada lahan-lahan dengan bentuk wilayah datar-berombak dan bergelombang dengan lereng $<15 \%$, kedalaman tanah minimal $50 \mathrm{~cm}$, tekstur dapat bervariasi mulai dari berliat sampai berpasir, dengan pola tanam tergantung pada ketersediaan air untuk pertumbuhan, pada umumnya hanya 1-2 kali tanam. Kenyataan di lapang, komoditas tanaman semusim ini ditanam di semua bentuk wilayah, bahkan di lahan berbukit dan bergunung dengan lereng curam $>30 \%$ tanaman tersebut masih diusahakan, padahal ditinjau dari aspek tata ruang dan lingkungan lahan tersebut diarahkan untuk tanaman tahunan atau hutan konservasi. Apalagi di wilayah dataran tinggi yang umumnya berupa pegunungan, tanaman semusim hortikultura (sayuran) banyak diusahakan dan sangat intensif pengelolaan lahannya, tanpa diiringi dengan penerapan teknologi konservasi, sehingga dengan tingginya curah hujan akan memacu terjadinya erosi dan degradasi lahan sulit dihindari. Hal ini yang belum banyak mendapat perhatian baik oleh masyarakat maupun para pengambil kebijakan (stakeholders). Untuk itu, perlu suatu upaya untuk mengurangi masalah tersebut di antaranya dengan memilih teknologi usahatani berbasis konservasi yang memadukan antara tanaman semusim, tanaman tahunan, dan hijauan pakan ternak secara proporsional, yang dapat meningkatkan pendapatan petani dan sekaligus mempertahankan lahan dari kerusakan lingkungan yang terus berlanjut. Arahan bentuk konservasi lahan dilakukan dengan metode teknis mekanik dan vegetatif, yaitu dengan membandingkan bentuk konservasi lahan dan penanaman tanaman alternatif yang dibandingkan dengan besar erosi lahan yang terjadi yang kemudian dilihat dengan kesesuaian fungsi kawasan berdasarkan karakteristik lahan tersebut. Fungsi kawasan pada daerah penelitian mencakup fungsi utama, yaitu :

1) Kawasan Fungsi Lindung

Pada kawasan fungsi lindung yang tidak terganggu dengan aktivitas pertanian, maka suatu alternatif yang dapat dilakukan adalah dengan mengembalikan fungsi hutan lindung pada wilayah tersebut, yaitu dengan cara mengambil alih lahan milik kehutanan yang telah disewakan pada pada masyarakat untuk dilakukan rehabilitasi hutan tanpa adanya kegiatan pertanian di wilayah fungsi lindung tersebut.

2) Kawasan Fungsi Penyangga dan Kawasan Fungsi Budidaya Tanaman Tahunan Konservasi lahan kawasan fungsi penyangga dan fungsi budidaya tanaman tahunan dapat diterapkan sejalan dengan kegiatan pertanian masyarakat, akan tetapi pada kawasan ini diperlukan suatu jenis tanaman keras untuk melindungi kawasan bawahannya, dapat berupa perkebunan atau hutan produksi terbatas. Alternatif pengelolaan lahan secara mekanis dan vegetatif dapat dilakukan dengan beberapa usaha konservasi secara terpadu sebagai berikut:

a) Wanatani (agroforestry) tanaman pangan pada perkebunan tanaman keras kopi. Kuantitas tanaman pangan disesuaikan dengan kemiringan lereng pada lahan tersebut sesuai dengan gambar 2 tentang acuan umum proporsi tanaman pada kemiringan lahan yang berbeda, yaitu pada kelerengan $<15 \%$

*) Hendro Murtianto, S.Pd., M.Si., adalah Dosen Jurusan Pendidikan Geografi FPIPS-UPI. 
dilakukan proporsi penanaman $25 \%$ tanaman tahunan dan $75 \%$ tanaman semusim; pada kelerengan $15-30 \%$ proporsi penanaman tanaman tahunan dan semusim adalah sama, yaitu $50 \%$; pada kemiringan lereng 30-40\% proporsi penanaman tanaman tahunan adalah $75 \%$ dan tanaman semusim $25 \%$; serta untuk kelerengan $>40 \%$ penerapan tanaman adalah tanaman tahunan saja, sebab pada kemiringan ini merupakan kriteria fungsi kawasan lindung.

b) Pemilihan tanaman keras kopi didasarkan pada pola budidaya masyarakat sekitar lereng Gunungapi Sindoro yang menanam kopi sebagai tanaman keras perkebunan, sehingga kopi merupakan tanaman keras yang sudah diberdayakan oleh masyarakat walaupun kuantitasnya sedikit dibandingkan dengan penanaman tembakau sebagai tanaman musim kering. Laporan Badan Penelitian dan Pengembangan Pertanian tentang Teknologi Pertanian Lahan Marginal (2004:11) menyebutkan bahwa untuk peningkatan perekonomian lahan kering di daerah lereng Gunungapi Sindoro dan Sumbing, Kabupaten Temanggung sesuai diterapkan penanaman tanaman keras/ perkebunan berupa kopi, untuk dataran rendah jenis kopi robusta dan dataran tinggi kopi arabika.Hal ini yang mendasari pemilihan kopi di daerah penelitian sebagai jenis alternatif tanaman keras mempunyai tingkat kesesuaian lahan terhadap kondisi fisik lahan tersebut.

c) Pemilihan tanaman semusim disesuaikan dengan kondisi kebiasaan masyarakat dalam mengusahakan tanaman pertanian, sehingga masyarakat tidak terlalu terbebani dengan penanaman jenis tanaman baru. Penanaman tanaman semusim dilakukan diantara tanaman keras sehingga kegiatan pertanian berlangsung sebagai kegiatan budidaya tanaman pangan diantara perkebunan yang telah direkomendasikan. Kegiatan pertanian terbatas diusahakan sebagai jalan peningkatan perekonomian masyarakat tanpa harus mengurangi fungsi kawasan yang ada dan sebagai bentuk penyokong usaha perkebunan sebagai tanaman pokok lahan menggantikan tanaman semusim tanpa tanaman keras.

d) Pemilihan pengelolaan lahan (P) dipilih dengan mempertimbangkan kondisi pengelolaan awal, besar erosi (A) dan erosi yang diperbolehkan (T). Pengelolaan lahan alternatif disusun dengan menekan seminimal mungkin perubahan yang terjadi pada relief mikro lahan, akan tetapi dapat menciptakan CP alternatif yang nilai A alternatifnya $\leq$ besar erosi (A). Pemilihan pengelolaan lahan, baik dengan teras guludan, teras kridit, dan bangku serta perlakukan penanaman tanaman pagar dan pertanaman lorong disesuaikan dengan tingkat kebutuhan berdasarkan syarat dan karakteristik fisik lahan di daerah penelitian. Seta (1991:30) menyatakan bahwa tanaman yang baik digunakan untuk tanaman pagar pada perkebunan kopi dan karet di Indonesia adalah lamtoro (Leucaena glauca). Tanaman ini memiliki keunggulan sebagai tanaman pagar di daerah lereng yang memiliki ketinggian hingga $1.500 \mathrm{dpal}$, memiliki sistem perakaran yang dalam, tahan pangkas, dan memberikan unsur nitrogen pada tanah dalam jumlah yang

*) Hendro Murtianto, S.Pd., M.Si., adalah Dosen Jurusan Pendidikan Geografi FPIPS-UPI. 
besar sebagai sumber bahan organic serta mulsa. Pangkasan dari tanaman pagar yang digunakan sebagai mulsa diharapkan dapat menyumbangkan hara terutama nitrogen. Tanaman penutup tanah rendah, dapat ditanam bersama tanaman pokok maupun menjelang tanaman pokok ditanam. Tanaman penutup tanah sedang dan tinggi pada dasarnya seperti tanaman sela dimana tanaman pokok ditanam di sela-sela tanaman penutup tanah. Dapat juga tanaman pokok ditanam setelah tanaman penutup tanah dipanen. Untuk perbaikan teras bangku, selain menanam tanaman pagar pada bibir teras, sebaiknya ditanam rumput pada tampingan teras. Rumput yang baik digunakan pada tampingan dan bersifat tebang pangkas menguntungkan bagi petani sebagai pakan ternak adalah rumput bede.

b. Pemberdayaan Masyarakat

Pemberdayaan masyarakat dalam keterkaitan konservasi lahan sangat diperlukan guna menanamkan sikap yang ramah lingkungan demi keberlangsungan usaha pertanian di kemudian hari dan menekan seminimal mungkin dampak kerusakan lingkungan yang disebabkan oleh adanya pengolahan lahan oleh masyarakat. Bentuk pemberdayaan masyarakat di daerah konservasi dapat berupa :

1) Program penguatan ekonomi masyarakat melalui pengembangan perdesaan, sehingga pendapatan petani meningkat.

2) Program pengembangan pertanian konservasi, sehingga dapat berfungsi produksi dan pelestarian sumber daya tanah dan air.

3) Penyuluhan dan transfer teknologi untuk menunjang program pertanian konservasi dan peningkatan kesadaran masyarakat untuk berpartisipasi dalam upaya konservasi lahan.

4) Pengembangan berbagai bentuk bantuan, baik berupa bantuan langsung maupun tidak langsung, dalam bentuk bantuan teknis, pinjaman, yang dapat memacu peningkatan produksi pertanian dan usaha konservasi tanah dan air.

5) . Upaya mengembangkan kemandirian dan memperkuat posisi tawar menawar masyarakat lapisan bawah, sehingga mampu memperluas keberdayaan masyarakat dan berkembangnya ekonomi rakyat.

6) Memonitor dan evaluasi terhadap perkembangan sosial ekonomi masyarakat, serta tingkat kesadaran masyarakat dalam ikut berperan serta dalam pengelolaan dan konservasi lahan.

\section{c. Penegasan Aturan Hukum yang Berlaku}

Penegasan aturan hukum yang berlaku dimaksudkan sebagai bentuk monitoring pemanfaatan lahan yang sesuai dengan fungsi kawasan, pembangunan tata ruang wilayah berdasarkan pada tingkat kemampuan dan kesesuaian lahannya. Suatu kawasan yang telah ditetapkan sebagai kawasan fungsi lindung harus semestinya tetap dilindungi dengan aturan hukum, tidak semestinya terjadi alih fungsi lahan yang berdasarkan keputusan sesaat yang hanya mementingkan kepentingan politik dan ekonomi saja. Pengawasan dan evaluasi harus terus

*) Hendro Murtianto, S.Pd., M.Si., adalah Dosen Jurusan Pendidikan Geografi FPIPS-UPI. 
diterapkan guna menuju suatu pengelolaan lahan yang berkelanjutan (sustainable development).

\section{Penutup}

Penataan ruang di suatu wilayah dilakukan dengan pertimbangan kemampuan wilayah berdasarkan karakteristik lahan yang bersangkutan. Penentuan fungsi kawasan untuk pemanfaatan tertentu dilakukan dengan pertimbanganpertimbangan karakteristik fisik dan sosial kemasyarakatan. Penataan ruang perlu dilakukan oleh berbagai pihak baik pemerintah ataupun masyarakat, guna saling mendukung program kelestarian lingkungan dan keruangan suatu wilayah. Pemanfaatan ruang yang sesuai dengan kemampuan wilayahnya diharapkan dapat memberikan dukungan bagi terpeliharanya lingkungan secara lestari dan mendukung bagi kehidupan manusia secara berkelanjutan. Pemberdayaan masyarakat untuk menjadi masyarakat yang sadar akan kondisi lingkungan akan sangat menentukan bagi suksesnya program penataan kawasan. Penataan kawasan tidak hanya berbasis pada peningkatan kegiatan ekonomi masyarakat, akan tetapi juga mempertimbangkan kelestarian lingkungan alam yang ada di sekitarnya.

\section{Daftar Pustaka}

Anonim. 2003. Pedoman Teknis Pengelolaan DAS Terpadu. Jakarta. TKPSDA.

Arsyad, S., 1989. Konservasi Tanah dan Air. Bogor: IPB Press.

Asdak, C., 2002. Hidrologi dan Pengelolaan Daerah Aliran Sungai. Yogyakarta: Gadjah Mada University Press.

Direktorat Jenderal Rehabilitasi Lahan dan Perhutanan Sosial: Departemen

Kehutanan. 2003. Rencana Teknik Lapangan Rehabilitasi Lahan dan Konservasi Tanah (RTL-RLKT).

Ditjen Perkebunan. 2000. Statistik Perkebunan Indonesia 1998-2000. Kopi (Coffee)

Departemen Kehutanan dan Perkebunan. Direktorat Jenderal Perkebunan. Jakarta. 2000.

Fahmudin, Widianto. 2004. Petunjuk Praktis Konservasi Tanah Pertanian Lahan Kering. Bogor : World Agroforestry Centre ICRAF Southeast Asia.

Hudson, N.W. 1976. Soil Conservation. Batsford Ltd. London.

Kartasapoetra, A.G. 1991. Teknologi Konservasi Tanah dan Air. Jakarta: Rhineka Cipta.

Morgan, RPC. 1995. Soil Erosion and Conservation 2nd ed. Longmand Group. UK.

*) Hendro Murtianto, S.Pd., M.Si., adalah Dosen Jurusan Pendidikan Geografi FPIPS-UPI. 